\title{
Second Culture, Good Vibrations, and Writings on the Wall: Hip-Hop in the GDR as a Case of Afro-Americanophilia
}

\author{
Leonard Schmieding, Georgetown University
}

As one of the last youth and pop cultures entering the world of socialism from the West, hip-hop found holes in the Iron Curtain and, starting in 1983, began to spread throughout the German Democratic Republic (GDR). When, five years after the release of the first rap song 'Rapper's Delight' by the Sugarhill Gang in 1979, West German radio stations like Sender Freies Berlin (SFB, Radio Free Berlin), Norddeutscher Rundfunk (NDR2, Northern German Broadcasting), and Bayerischer Rundfunk (BR2, Bavarian Broadcasting) played rap music in their charts, they could also count on numerous East German youngsters being in their audience, given the failure of the GDR to jam airwaves coming from the West. Tuning into the new world of sound that hiphop created, these members of the audience were fascinated by rhythms, mixes of old and new, and lyrics. Similarly, breakdance performances by the Rock Steady Crew and the New York City Breakers on West German TV shows hosted by Thomas Gottschalk and Hans-Joachim Fuchsberger helped many subsequent East German b-boys pick up their first moves. The latter enthusiastically took part in the cultural transfer of rap, bboying (also more commonly known as breakdance), deejaying, and graffiti into the GDR, creating their own world of hip-hop east of the Iron Curtain. After Harry Belafonte's movie Beat Street (1984) premiered in the GDR on 14 June 1985, only a year after its release in France, Great Britain, and West Germany, the local hip-hop 
scene really started to flourish. ${ }^{1}$

The cultural transfer of hip-hop was enabled by diverse strands of AfroAmericanophilia. On the one hand, officials from the Socialist Unity Party (the SED, a.k.a. Communist Party) and the State's cultural functionaries who sought to monitor, control, and organize youth culture, expressed a certain appreciation for African American culture. In their view, the black population in the USA in the 1980s still belonged to the oppressed and exploited working class, with whom the GDR ought to show political and cultural solidarity. The reaction of authorities to hip-hop thus resembled earlier German leftist patterns of perceiving African American culture. As Uta Poiger points out in her study Jazz, Rock, and Rebels, communists in Weimar Germany protested against black artists performing for bourgeois audiences, and suggested that their performances should criticize colonial exploitation and feature rebellion instead (2002: 21). In the immediate postwar years jazz was met with suspicion, in both West and East Germany. Under the influence of 'jazz pope' JoachimErnst Berendt, jazz was de-coupled in the West from its earlier racist associations with racial degeneration, primitiveness, and feminization and became a respectable music of modernity in the 1950s (Poiger 2002: 142; Hurley 2009). ${ }^{2}$ In East Germany, racist connotations continued to persist, at least in relation to some jazz. The Leipzig sociologist Reginald Rudorf distinguished between commercialized forms of jazz like swing and bebop on the one hand, which he called degenerate and regarded as part of Cold War American imperialist strategies, and 'authentic' jazz on the other hand, like blues, spirituals, and Dixieland, which he understood as true expressions of African American folk culture, and which he deemed as conducive to stimulating the evolution of a new socialist German dance culture (Poiger 2002: 150-53). In this vein, the cultural and political authorities made the African American singer Paul Robeson their role model for the interpretation of 'true' folklore, anti-imperialist resistance, and communism. He served as the opposite of rock ' $n$ ' roll, which, for the socialist state, held no positive value at all and was seen as the harbinger of a new world war in the 1950s (Rauhut 2011: 96-100; Poiger 2002: 158). Although the discussion of African

\footnotetext{
${ }^{1}$ For the influence of Beat Street on the development of hip-hop in the GDR, see Schmieding (2011; 2012). For a discussion of the early reception of hip-hop culture in West Germany, see Ege and Hurley's second jointly authored survey essay in this special issue, and the scholarship they refer to.

${ }^{2}$ This process was highly ambivalent given that Berendt appreciated bebop and cool jazz as high culture, but looked down upon swing as working-class culture (Poiger 2002: 145). Refer also to Hurley's paper in this special issue where he discusses Berendt's ambivalent feelings towards 'Swingheinis.'
} 
American music lost some of its fire during the reign of Erich Honecker, the advent of hip-hop revived public interest and forced the regime to react to the newest black cultural import.

Somewhat removed from these public debates, East German teenagers were fascinated by the innovative, creative, and playful techniques they found in hip-hop culture's constituent elements of b-boying, graffiti, rap and deejaying. With these practices, they not only found new modes of expressing themselves in a way that the controlling agencies could not decipher, but they also imagined themselves to be in New York City, thus taking a temporary break from the constraints of the GDR. Similar to the authorities who sought to control them, the East German hip-hoppers' appropriation of black culture was also rooted in a distinctly German history of dealing with African American culture. Members of the Youth culture found allies in African Americans, as Poiger has shown in her discussion of the movie Blackboard Jungle (1955) and its resonance among West German viewers. This affinity suggested that Germans could see themselves as victims - of displacement, economic hardship, and the occupying forces (2002: 88). East German adolescents found traces of their African American allies in the blues, since this music projected 'authenticity,' promised 'pure emotion' and symbolized historical suffering: 'The blues became an escape, idealized as a counterworld to the GDR system of social tutelage' (Rauhut 2011: 105-107). Analogous to the young blues fans of the previous generation, hip-hop heads make their escape by way of breakdance, graffiti, deejaying and rap.

In order to do so, many of them 'became black,' I argue, referring to Moritz Ege's study Schwarz Werden about Afro-Americanophilia in West Germany around 1968 (2007). I follow his definition of Afro-Americanophilia as a cultural theme: the appreciative appropriation and perception of cultural forms encoded as 'black' and the analogous relationship felt towards black people and/or representations of them. Becoming black, then, as a heuristic term for analysis, means an imaginary and symbolic identification with African Americans (Ege 2007: 11-12). Consequently, my central question is: What was Afro-Americanophilia in the GDR during the 1980s?

In order to answer my question, I will, in the following, analyze three individuals' love of African Americans and black culture: a cultural critic explaining hip-hop for cultural functionaries; a radio host running a black music program in East Berlin; and a young 
graffiti writer in Dresden. In all three cases I focus on the cultural work that their interpretation and/or practices of hip-hop did, and I detail how that work facilitated the emergence and development of a hip-hop scene amongst young East Germans. In the first case, I scrutinize how the cultural critic Erhart Ertel used Marxist-Leninist theory to perceive hip-hop as 'second culture,' and how this favorable representation paved the way for hip-hop to be embraced by socialist cultural organizations. My analysis also elaborates the shortcomings in this Marxist-Leninist interpretation, which not only excluded race as an explanatory category, but also failed to develop a socialist vocabulary to grapple with aspects including graffiti, rap and deejaying. The second case study zooms in on the radio host Lutz Schramm and his program 'Vibrationen' [Vibrations] for the State-run Jugendradio DT64 [Youth Radio DT64]. By looking at both Schramm's moderation and the music he played, I analyze his ambivalent role as an actor on behalf of the State: He worked as an employee of the State-run radio in East Berlin, a socialist mass medium that intended to educate socialist youngsters and instill in them an aversion against capitalism. However, in the process, he also fed rap-hungry teenagers the American music they desired, information about the hip-hop scene in the United States, and songs they could use in their own practice of hip-hop. Lastly, I give a case study of the graffiti 'writer,' Simo, from Dresden. This case study shows how Simo imagined himself into New York, the mecca of hip-hop, how he fashioned himself as a black writer, and how he connected with the hip-hop scene all over the GDR.

\section{Hip-hop as second culture: Official perspectives on blackness in East Germany}

Four months after Beat Street premiered in East German movie theaters in June 1985, the periodical Informationen der Generaldirektion beim Komitee für Unterhaltungskunst [Information from the General Sub-Committee for the Entertainment Arts] published an essay about hip-hop culture by the cultural critic Erhart Ertel, a Professor for Theater and Performance Studies in East Berlin (Ertel 1985). Under the heading 'Breakdance. Anmerkungen zu einer "zweiten Kultur"” [Breakdance: Comments on a 'Second Culture'], Ertel explained hip-hop in the USA by referring to the Marxist-Leninist term second culture. He ended his essay by fashioning hip-hop as a desirable practice for socialism and recommending its incorporation into the official cultural landscape of the GDR. While his perspective on hip-hop expressed a general appreciation of African American culture, it, ironically, disregarded black cultural achievements and traditions. Instead, it focused on aspects of capitalist 
exploitation, discrimination, and oppression - thus preferring a mode of explication that was based on class and not on race and/or ethnicity.

Ertel explicitly distinguished breakdance from other dance fashions such as rock ' $n$ ' roll and the twist. In fact, the term 'dance' was inaccurate, since it ignored breakdance's artistic and aesthetic qualities as well as its sociocultural meanings. He aimed to look behind the commodification of breakdance, and analyze its original context, shape, and function as a form of second culture: 'Er ist ein produktives Beispiel der Herausbildung einer "zweiten Kultur" (Lenin) in der spätbürgerlichen Gesellschaft und eine spezifische Erscheinungsform darstellender Kunst von hoher artifizieller Attraktivität und sozialer Verbindlichkeit' [It is a productive example of the emergence of a 'second culture' (Lenin) in late bourgeois society, and a specific form in the performing arts, highly attractive and socially engaging] (1985: 2). ${ }^{3}$ Whilst his contemporary audience was familiar with Lenin's concept of second culture, today's readers need an explanation.

According to Lenin's Kritische Bemerkungen zur nationalen Frage [Critical Remarks on the National Question], Ertel's major theoretical reference, there are two cultures in each nation, a hegemonic bourgeois one and a socialist-democratic one: '[D]enn in jeder Nation gibt es eine werktätige und ausgebeutete Masse, deren Lebensbedingungen unvermeidlich eine demokratische und sozialistische Ideologie erzeugen' [For in every nation, there is an exploited working class, whose living conditions unavoidably create a democratic and socialist ideology] (1980: 13). Under the ideology of the 'internationalen Kultur des Demokratismus und der Arbeiterbewegung der ganzen Welt' [international culture of democratism and the global labor movement], second culture is the 'Gegengewicht zur bürgerlichen Kultur, zum bürgerlichen Nationalismus jeder Nation' [counter-weight to bourgeois culture, and to every nation's bourgeois nationalism] (1980: 14). East German historian Jürgen Kuczynski, Ertel's second authority on the theory of culture, develops Lenin's concept to provide a task to the ruling Socialist Unity Party: to politicize the working class on the basis of Marx's and Engels's writings and to thus form a second culture, a working class culture (1982: 242).

Kuczynski sees the main difference between bourgeois and working-class culture in the 'alternativen Ideen über die Natur der gesellschaftlichen Beziehungen' [alternative ideas

\footnotetext{
${ }^{3}$ Unless otherwise noted, all translations are mine.
} 
about the nature of social relations] (1982: 228). His conception of cultural history intends to 'die tatsächlich schon in der Lebensweise vorhandene vollständige oder teilweise Verwirklichung solcher Ideen auf[zu]spüren' [trace out the partial or fully extant forms of realization of these ideas in the practice of life] (1982: 282). The meaning of second culture, then, has a strong political implication: 'Die zweite Kultur, die Kultur der Arbeiterklasse, ist Bestandteil des Kampfes dieser Klasse um die Macht. Die Kultur ist jedoch nicht nur ein Mittel, um die Macht zu erobern, sie ist vielmehr auch selbst Macht, Machteroberung, Machterhaltung. Mit dem Wachsen einer zweiten Kultur wächst die Macht der Arbeiterklasse' [Second culture is the culture of the working class, it is a part of this class's struggle for power. Culture is not only a means to seize power, it is much rather power in itself, it is the seizure of power and its maintenance. With the growth of a second culture, the power of the working class increases] (1982: 229). Furthermore, Kuczynski follows a holistic approach to culture, in the Marxist sense of appropriating the world, and he underscores the importance of differentiating between the disempowered practice of copying hegemonic culture and the empowering practice of creating working class culture.

Based on these Marxist-Leninist concepts of nation, the working class, and culture, Ertel evoked a specific image of 'America.' In his view, the working class consisted primarily of exploited and oppressed African Americans, and in New York City, of Puerto Rican immigrants too. In order to render these minorities' everyday workingclass life, he referred to Beat Street and to two travelogues, one from Denmark, the other from East Germany. The first travelogue was Jacob Holdt's Amerikanische Bilder: eine Reise durch das schwarze Amerika [American Images: A Journey through Black America] (1984). Holdt was a Danish pastor's son who had hitchhiked his way through the USA from 1970 to 1975 and had met the poorest of the poor in the process. He documented his encounters and experiences in letters and about 15,000 photographs taken during his five years on the road. In 1977 he published this collection in West Germany, and in 1980 the book was also became available in East Germany as a licensed copy. In his chapter 'Weihnachten in New York' [Christmas in New York], Holdt included all boroughs of the city but focused on the marginalized: poor people, drug addicts, and the homeless, the majority of whom were African American. His photographs of heavy demolition machinery in the Bronx, poised to tear down the ruins of arson-damaged houses, of housing projects containing abominable poverty, and of 
crack dens, demonstrated the ghetto existing in the USA's largest metropolis.

Documenting how 'the other half' lived, these pictures decried capitalist America's inequality. For the East German State and for SED officials, Holdt's book represented an authentic accusation against their class enemy. The fact that Holdt prefaced his book with a quote by the Cuban hero, José Martí, and dedicated it to 'the miracle,' Fidel Castro, made it all the more suitable.

Hence it comes as no surprise that Ertel used Holdt to speak about the ghetto and the ghettoization of African Americans.

\begin{abstract}
Aber Harlem ist nicht das einzige Ghetto in New York und noch lange nicht das schlimmste. Im Stadtteil Bronx gibt es Gebiete, wo neun von zehn Menschen eines unnatürlichen Todes sterbenwegen Hunger, einer Überdosis Heroin, Rattenbissen (Säuglinge) oder Mord. Auch ist das Brooklyn-Ghetto größer als Harlem. In Brownsville sah ich zwei Morde und hörte am selben Tag von vier weiteren; ich bin seitdem nicht wieder dort gewesen. (Holdt 1984: 161, as cited in Ertel 1985: 5)

[But Harlem is not the only ghetto in New York, and it's by far not the worst. In the Bronx, there are areas where nine out of ten people die an unnatural death-because of hunger, an overdose of heroin, rat bites (newborns), or murder. Also, the Brooklyn ghetto is bigger than Harlem. I witnessed two murders in Brownsville and heard of four more on the same day; I haven't been there since.]
\end{abstract}

This text directly follows a series of color photographs that depict ghetto graffiti, both in the Latin American mural tradition, and in the new hip-hop style (1984: 150-160). ${ }^{4}$ Since Ertel did not tire from mentioning the ghetto, mass unemployment, and African Americans in his account of hip-hop, it is likely that Holdt's pictures, along with his observations and judgment of the USA, were the former's major influence when writing about the phenomenon's emergence in New York City. Holdt's work clearly lent itself well to Marxist-Leninist interpretations of African American culture as second culture.

The second travelogue that Ertel used as a source was the East-German journalist David Fischer's New York: Glanz und Elend einer großen Stadt [New York: The Splendour and Misery of a Big City] (1983). Fischer's book has less pictures but makes up for the lack of visual information with dramatic descriptions of New York's unemployment, violence and crime. Chapter headings like 'Die unregierbare Stadt' [The Un-governable City] and 'Welthauptstadt des Verbrechens' [The World's Crime Capital] suggest a narrative of death and decay (1983: 137-152). In particular, Fischer extensively quotes everyday voices worried about unemployed young people: Boredom is a breeding

\footnotetext{
4 The photographs document writers' 'tags' and 'pieces' on subway carriages, and are most likely the first depictions of hip-hop graffiti available in Europe.
} 
ground for 'die Anziehungskraft der Gangs' [the attractiveness of gangs] and the 'die Hoffnung, bei ihnen eine Heimat zu finden, ein Zuhause, und vielleicht mit ihnen die Not und das Elend zu überwinden, reich zu werden. Und wenn schon nicht reich, dann vielleicht wenigstens berühmt!' [hope to find a home in them, to overcome hardship with their help, and maybe to get rich. And if not rich, then at least famous!] (1983: 149, as cited in Ertel 1985: 5). By focusing on Fischer's point about the problem of boredom, Ertel emphasizes the nexus between unemployment and the loss of an occupation, which deprives individuals of the ability to self-actualize and self-validate. The gang is one way out of this situation, another is hip-hop:

\footnotetext{
Die sich hier in der Tendenz zum Verbrechen äußernden Haltungen und Verhaltensmuster sind denen, wie sie im Breakdance zum Tragen kommen, nicht unähnlich, was nicht verwundert, entspringen sie doch den gleichen sozialen Gegebenheiten. (Ertel 1985: 5)

[The attitudes and patterns of behaviour which express themselves here in a tendency towards crime are not dissimilar to those which manifest themselves elsewhere in breakdance, which comes as no surprise, because they are rooted in the same social circumstances, after all.]
}

Ertel locates hip-hop culture in a specific image of the USA - one characterized by capitalist exploitation, marginalization of African Americans, and mass unemployment in the metropolitan ghetto. In this context, hip-hop, as an interplay of breakdance, graffiti and rap, is second culture that emerges from the living conditions of young African Americans and Puerto Ricans in New York City (Ertel 1985: 4).

Explaining hip-hop as second culture foregrounds economic aspects, and therefore the terms labor and production are central to Ertel's analysis. He looks first at breakdance and then at graffiti and rap. According to his analysis, unemployment and exclusion from production - both high in the non-white population - have two effects. First, traditional modes of self-actualization are not possible and trigger the search for new ones. Second, the structural difference between work and leisure collapses, which has an impact on how people view, perceive, and receive art. In capitalist society, Ertel argues, over-consumption can numb people and thus render them incapable of engaging with art. In breakdance, however, African American teenagers have overcome the danger by attaining a new mode of self-actualization, one that protests against social conditions in a practical way. Ertel concludes: 'Die antikapitalistische Tendenz einer derartigen Bewegung ist in diesem Ansatz ebenso erkennbar, wie sie in der konkreten Ausprägung des Breakdance ihre Bestätigung erfährt' [The anti-capitalist tendency of such a movement can be clearly identified in this approach, just as it is confirmed in the 
concrete practice of breakdance] (1985: 4). In other words, hip-hop is not only the culture of the working class, but as second culture it actively joins the class struggle.

This function can also be observed in graffiti, as Ertel continues: 'In ähnlicher Weise ist auf dem Gebiet der bildenden Kunst die Graffiti-Bewegung zu begreifen, die kaum zufällig in der South Bronx eine gleichsam große Bedeutung erlangte und z.T. die Personalunion von Breakdancer und Graffitikünstler zu beobachten ist [sic]' [In the field of visual arts, the graffiti movement has to be understood in similar terms. It is not by coincidence that it gained a similarly high level importance in the South Bronx, and that it is sometimes practiced by artists who are simultaneously b-boys] (1985: 6). As political and social messages, graffiti deconstruct hegemonic strategies and occupy the public urban space. Graffiti 'pieces' on subway trains have even become moving art exhibitions, challenging traditional systems of communication. Like breakdance, then, graffiti is 'kultureller Widerstand und Ausdruck eigenen Lebenswillens' [cultural resistance and an expression of the will to live one's own life] (1985: 7). The general absence of Marxist-Leninist vocabulary in this interpretation of graffiti is conspicuous, however. It anticipates the official helplessness the State faced when trying to come to terms with graffiti in East Germany. Not only were the individual symbols difficult to decode, but it proved impossible to translate graffiti's social and cultural functions into socialism. But then how could one find a place for practices that occupied public space and deconstructed hegemonic discourse within a political system that relied on controlling the public and did everything to guard its ruling discourse.

The role of public space is central to rap as well, Ertel explains. Young African American rappers' lyrics refer to their experiences in the metropolis. As with breakdance, rappers play with their reality so as to alter and deconstruct it:

Für Rap-Musik und Breakdance auffällig ist der rigorose und dabei kreative Umgang mit den Versatzstücken der erlebten großstädtischen, in erster Linie auch durch die Medien vermittelten Kultur. ... Dieser aktive Umgang mit den Versatzstücken einer Kultur ist als Ausdruck ihrer souveränen Beherrschung, Zerstörung und neuen Sinngebung zu verstehen. Damit begegnet man einer aktiven Protesthaltung gegenüber einer Kultur, die eigentlich selbst durch ihre Präsenz, der kaum zu entkommen ist, vergewaltigende Wirkung hat. Diese vergewaltigende, damit beherrschende Situation findet im Rap eine Umkehrung. (Ertel 1985: 8)

[In rap music and in breakdance, it is striking how [the artists] use the constituents of their metropolitan culture so rigorously and creatively, a culture which they know primarily through the media ... This active use of cultural constituents is to be understood in terms of [the rappers expressing] sovereignty, deconstruction, and re-ascribing meaning. Here, we find active protest against a culture, which already through its inescapable presence has a raping effect. This raping and thus dominating situation is reversed in rap.] 
Ertel thereby identifies the potential for protest in rap. As with graffiti, however, he does not use Marxist-Leninist vocabulary to interpret the cultural function of rap. It is telling that in his elaborations about hip-hop in the GDR he only engages with breakdance and its possible functions in socialist terms. Moreover, it is astonishing that the development of hip-hop in East Germany actually came to mirror his discourse. That is, while cultural functionaries successfully disciplined, controlled, and instrumentalized breakdance, which Ertel analyzed for them in Marxist-Leninist terms, they were unable to grasp graffiti, deejaying and rap, for which he had no vocabulary.

In his commentary on hip-hop Ertel predicts that breakdance lacks the potential to grow into a mass movement in the GDR. Pointing to Beat Street's appeal to a teenage audience, he states: 'Auch die Aufnahme des von ... Harry Belafonte produzierten Streifens "Beat Street" in unsere Kinospielpläne wird zwar die Begeisterung für den Breakdance und seine Bewunderung auffrischen, kaum aber den praktischen Nachvollzug beleben' [Even the inclusion in our film programs of ... Harry Belafonte's movie 'Beat Street' will not trigger its practical emulation, although it will invigorate the enthusiasm for breakdance] (Ertel 1985: 9). He appreciates that breakdance might be appropriated in the GDR because hip-hop, as second culture, is working-class culture, and he even argues that interested teenagers should be supported in their endeavours, since breakdancing is to be preferred to more passive cultural activities (1985: 9). (Even in the socialist cultural landscape, he admits, most forms of leisure rely on passive reception, and thus fall into the spurned category of consumption.) Overall, breakdance has an activating character, and it should therefore be supported.

In order to corroborate his argument, Ertel analyzes how breakdance changes its social function within the process of cultural transfer:

\footnotetext{
Natürlich wird der Breakdance nur in seinen ursprünglichen sozialen Umfeldbedingungen in seiner Ganzheitlichkeit in Erscheinung treten, wird er nur dort die weiter oben benannten sozialen Funktionen realisieren ... Breakdance wird letztlich in der sozialistischen Gesellschaft weniger in seiner ganzen Komplexität als in bestimmten Aspekten aufgegriffen. Der Aneignungsprozess erfolgt dabei, was natürlich ist, mehr sporadisch als auf der Basis konzeptionellen Nachdenkens. Diese sporadische Durchsetzung ist schon deshalb unproblematisch, eher natürlich, weil geprägt durch das Wirksamwerden eines der sozialistischen Gesellschaft gemäßen Lebenszusammenhanges.
}

[Breakdance, of course, will only fully emerge and realise the social functions mentioned above in its original societal circumstances ... In socialism, breakdance is ultimately only partially seized upon, rather than in its full complexity. Naturally, the process of appropriation occurs sporadically rather than on the basis of conceptualized reflection. And this sporadic development is 
unproblematic precisely because it is imprinted by the operation of a life context that is tailored to a socialist society.] (1985: 9)

With the absence of unemployment in socialism, other realities will inform breakdance. The essential difference between breakdance in capitalism and breakdance in socialism, according to Ertel, is the following: In the former, breakdance is the only form of selfactualization available, whereas in the latter, it is just one of many such forms from which to choose, which, in turn, have positive repercussions for socialism (1985: 9f).

The way Ertel fashioned breakdance as a desirable cultural practice paved the way for its swift incorporation into the cultural mainstream of State socialism. Dutifully following Marxist-Leninist ideology, he focused on the capitalist mechanisms of economic exploitation in the USA, regardless of race. In the process, he ignored the rich cultural heritage of African American practices dealing with the experience of racist discrimination. Hip-hop, as a derivative of blues and jazz, was thus severed from African American cultural production. In his attempts to decode the semiotics of hiphop culture, Ertel inscribed new meanings on it by prioritizing economic explanations over aspects of race or ethnicity. ${ }^{5}$ Whilst his interpretation may have been partly enabled by the polysemiology of contemporary (black) popular culture, his reading of hip-hop owed much to the rigid ideology of Marxism-Leninism, which ignored race and racism as analytic categories. It thus ultimately illustrated another German uncertainty about just how to respond to African American cultural products. Hence, 'areas of uncertainty,' which Kusmierz has diagnosed within the West German reception of Spike Lee movies and hip-hop culture, also characterized official GDR attitudes - the State's Afro-Americanophilia - towards hip-hop, albeit in different ways (2002: 168).

\section{Good vibrations: Lutz Schramm's black music radio on DT64}

The Jugendradio DT64 program 'Vibrationen' [Vibrations] contributed heavily to spreading hip-hop across East Germany. Hosted by Lutz Schramm, it ran as a 'black music' broadcast and featured rock steady, ska, and African music in addition to hiphop. On its first program on 13 January 1988, there were eleven rap songs, ten of which

\footnotetext{
${ }^{5}$ It is important to note that inscribing new contents into existing texts is usually the strategy of practitioners involved in the transfer of a cultural practice. For the West German case of hip-hop, see Ribbat (2000) and Kusmierz (2002). Cultural scholars in the GDR, however, applied this strategy deliberately, serving the aims and ends of the dictatorship: contributing to a hegemonic discourse in order to maintain cultural and political authority. Consequently, this difference between East and West calls for an awareness concerning the use of Cultural Studies' terminology - key terms like power, pleasure, and freedom are imbued with different meanings, which have to be historicized.
} 
were from the USA, and one from the GDR (Schramm 1988b). ${ }^{6}$ Schramm maintained this ratio between dominant American hip-hop and East German productions until the program was terminated in September 1991.

Lutz Schramm acted on behalf of the State. He nevertheless helped the evolving East German hip-hop scene to tune in to the transnational community of hip-hop. As he had done with other musical subcultures in earlier programs, he functioned here as a 'trailblazer of the underground' (Rauhut 2002). By playing US rap tunes and talking about the performers, he mediated hip-hop knowledge to his listeners, and in the process they became a participating audience (Schmieding 2012). As a radio host, he delivered aural versions of 'America' to his audience, and then contextualized these sounds by reference to an interpretation of hip-hop culture. ${ }^{7}$ The fact that hip-hop was officially understood as a form of second culture and hence mandated an expression of solidarity with its anti-capitalist American practitioners certainly made it easier for Schramm to create his program. But his role was that of a 'trickster' (Hyde 1998). For the cultural functionaries' ears he communicated perspectives on hip-hop that were officially accepted, and even called for. For his young audience, however, he played the music they appreciated, which he could do precisely because he accompanied his musical selections with ostensibly 'socialist' interpretations. In addition, Schramm functioned as a relay for information regarding the activities of the local scene. He announced events, interviewed artists and presented their productions, sometimes even as live-recordings from recent concerts.

\footnotetext{
${ }^{6}$ The US tracks included, for example, 'Funk Jam Party' by Africa Bambaataa, 'The Bronx' by Kurtis Blow, and 'He's the DJ, I'm the Rapper' by DJ Jazzy Jeff.

7 'Vibrationen' was neither the first nor the only program Lutz Schramm hosted on DT64. By this time he he had won the trust of his superiors such that he had carved out a relatively free space in which to create his shows.

Concerning censorship, he stated in 1987:

Ich spiele das, was ich verantworten kann. Das meint, was ich meinen Chefs gegenüber verantworten kann als auch mir gegenüber. Ich habe natürlich auch eine bestimmte politische Einstellung und setze mir selber Grenzen und muss natürlich auch immer daran denken, dass es ein DDR-Rundunk ist und ein Medium, was eine bestimmte Politik vertritt. Aber ich spiele im Prinzip auch Sachen, die ... musikalisch sehr extrem sind. In der Regel scheitert's dann eher an den technischen Grenzen, an den technischen Toleranzen als an den inhaltlichen. (cited in Larkey 2007: 174)

[I play whatever I can account for. That is, what I can take the responsibility for vis-à-vis my bosses and what I can live with myself. I have a certain political attitude and set limits for myself, and I have to constantly be aware of the fact that this is radio in the GDR, a medium with a certain political program. But I also play songs which are ... extreme, musically speaking. If a song cannot be played, it's usually because of our technical limits, not because of explicit content]. (my translation)
} 
The conditio sine qua non for Lutz Schramm's multifaceted role was that, as a black music special, 'Vibrationen' belonged to DT64's innovations in the 1980s, which meant that he had substantial freedom with his programming. In the following discussion, I provide an overview of the program's history up to the end of 1989 and then focus on one specific broadcast from 21 September 1988, in which he presented Public Enemy's current release, the LP It takes a Nation of Millions to Hold Us Back (Schramm 1988c).

'Vibrationen,' which as we have seen was devoted to 'black music' more broadly, had run 78 episodes by the end of 1989. Schramm curated about a third of them, 22 episodes in all, as special hip-hop programs, playing (mainly US) rap, as well as reporting on the local scene, and interviewing East German hip-hop artists. The format proved so successful in its first year that at the beginning of 1989, Schramm was permitted to broadcast 'Vibrationen' every Thursday, rather than twice a month. One program per month would now be devoted to hip-hop.

'Vibrationen' had a dual impact. First, Party and State officials adjudged whether the program fulfilled its educational purpose, but as they could only do so on the basis of easily accessible information, they probably only took Schramm's spoken moderation into account, and did not inquire independently into the English-language lyrics of the US tracks. Schramm made this task easy for them in the sense that his moderation paraphrased the lyrics, thus providing a kind of translation, and that he glossed the US artists' understanding of rap and hip-hop culture. He presented their productions as a protest against capitalism, consumer culture, and racism in the USA. ${ }^{8}$ His interpretation thereby fashioned hip-hop as second culture in the sense that Erhard Ertel analyzed it, and therefore would have been appreciated by the cultural functionaries controlling the program. Thus mediated, the music itself, which made up for most of the show, could sound inconspicuous and harmless, regardless of what the sometimes incomprehensible English lyrics might be saying. ${ }^{9}$

Schramm's young audience tuned into his program precisely because it could hear US hip-hop on it. As a soundtrack for b-boy routines or as raw material for deejays and

\footnotetext{
${ }^{8}$ Schramm thus continued the state radio's tradition of featuring African American artists for their criticism of capitalism, voices against racist oppression, and authenticity (Larkey 2007: 126).

${ }^{9}$ Edward Larkey points out that lyrics might not have been as important as they might have been, given that they no longer were subject to political assessment (censorship) and teenage listeners cared more about the sound than the text (2007: 173).
} 
rappers to use in their mixes and rhymes, 'Vibrationen' offered an up-to-date repository of sounds and texts with which to practice hip-hop. Recorded off the air onto tape and suitably edited, they were soon ready to be played loudly on the hip-hoppers' boom boxes, as they rambled through the cities of East Germany. ${ }^{10}$ As b-boy Salli of the crew Melodic Dancer from Stralsund remembers: '[Vibrationen] war ... für die angehenden Rapper der damaligen Zeit die Sendung mit dem meisten Potenzial, für uns als Tänzer war es die Sendung um an tanzbare Musik zu kommen' [For the rappers back then it (Vibrationen) was the program with the most potential, for us as dancers it was the program to get music] (Salewski 2012b). Testifying to the intensity with which they followed the program, he adds:
Also bei mir war es ja so, das das Tanzen wichtiger war, als die Rapper, die die Musik dazu beisteuerten. Natürlich war Musik in guter Qualität immer willkommen, also griff man auch auf Sendungen von diversen DDR-Sendern zurück und wenn es sich vereinbaren ließ, saß man vor dem Radio oder stellte eine- genau zugehört- selbstgebaute Zeitschaltuhr auf die Zeiten, wenn die Sendung lief, um somit kein Training oder Auftritt zu verpassen und am nächsten Tag wurde dann die Sendung auf das Benötigte beschnitten. Für unsere Rapper kann ich soviel sagen, und das sieht man ja an den Kommentaren einzelner Personen, für sie war "Vibrationen" so das NONPLUSULTRA. Sie beschäftigten sich ja mit der Musikszene, standen somit besser im Stoff als wir Tänzer und nutzten diese Sendungen regelmäßig. (Salewski 2012a)

\begin{abstract}
of good quality was always welcome, so we also listened to several radio programs in the GDR. When feasible, we sat in front of the radio or set a self-made clock timer to record the program so that we would neither miss the program nor practice or performance. The next day, we cut the recording to the music we needed. For our rappers - you can see that in the commentaries'Vibrationen' was the NONPLUSULTRA. They were really into this music scene and knew the material much better than we dancers, and they used these programs regularly.]
\end{abstract}
[For me dancing was more important than the rappers who contributed the music. Of course, music

Ironically, once Schramm's moderation was edited from the music, his shows were now impossible to distinguish from the sounds emanating from the radio stations of the 'class enemy' in West Germany and Western Europe more broadly. In addition to this vital supply of musical material, Schramm's young audience learned about the newest developments of hip-hop culture in the USA, since Schramm's presentations went beyond socialist readings of individual songs to also narrate hip-hop history and explain special techniques like rapping and deejaying, thus meeting written requests from his listeners (Schramm 1988a). In sum, then, 'Vibrationen' transported sounds, knowledge, and ideas about hip-hop through the Iron Curtain. In the process, it accommodated the

\footnotetext{
${ }^{10}$ This appropriation of 'Vibrationen' seems to have been standard practice among hip-hop heads, as it figures prominently in the personal interviews I conducted with former b-boys, deejays, and rappers (see, for example, DJ Opossum 2005; DJ Gambler 2008; TJ Big Blaster Electric Boogie, Andy K, Tommy, 2008).
} 
different manifestations of Afro-Americanophilia held by both the official State audience and the grass roots scene.

The episode broadcast on 21 September 1988 illustrates how the ambiguities of 'Vibrationen' played out. In this episode Schramm reviewed Public Enemy's second record, It Takes a Nation of Millions to Hold Us Back, which had been released on 14 April, 'mit einem ganz speziellen Hip Hop Programm' [with a very special hip-hop program] (Schramm 1988c). He interpreted the track, 'Don't Believe the Hype,' as a charge not to believe the record industry's promises, and this motif served as a cue for his ensuing characterization of the group:

Die Aufforderung, sich nicht gutgläubig dem preiszugeben, was Radio und Musikpresse (und nicht nur die) so in die Hirne junger Musikkonsumenten blasen, ist natürlich recht selten von einer PopBand zu hören. Chuck D. und Flavor Flav von Public Enemy predigen diese Weißheit [sic] aber nicht nur als Musiker, sondern auch als ehemalige Radio DJs. Für beide hat es vor 4 Jahren in einer New Yorker College-Station begonnen, wo sie die Möglichkeit, 9 Stunden pro Wochenende Hip Hop zu spielen auch dazu nutzten, ihre politischen Ansichten unter die Leute zu bringen. (Schramm 1988c)

[The demand to not naively believe what radio, music journalism, and other media are stuffing into their young consumers' heads is very seldom heard from a pop band. Chuck D. and Flavor Flav of Public Enemy preach this whiteness [sic; this could also mean Weisheit, that is, wisdom] not only as musicians but also as former radio DJs. Both started their careers 4 years ago at a college station in New York, where they used their nine hours of hip-hop airplay per weekend to also communicate their political views to the audience.]

To the ears of socialist functionaries, commending politically active musicians for criticizing capitalist consumer culture must have sounded like second culture. Teenagers, however, had just enjoyed listening to 'Don't believe the Hype' and were not necessarily susceptible to official political indoctrination via hip-hop. If they had been, the message they heard might also have been not to listen to the ideologically charged 'hype' of the socialist mass media! Notwithstanding that ambiguity, the young hip-hop heads were probably more interested in the second part of the announcement, anyway. Here they were informed that the two rappers had worked as deejays and could spin records for an enviable nine hours per weekend. Compared to the one hour of 'Vibrationen' per month, which came with a lot of commentary that they were not necessarily interested in, such a story fed into their fantasy image of New York City as a hip-hop paradise.

Another of Schramm's announcements described Public Enemy's political beliefs, class struggle, their anti-racism, and sounds as something like second culture. It may well 
have been more accommodating to the authorities, again, than to his young audience:

\begin{abstract}
Als gutgläubige Moslems und Befürworter der Black Panther-Bewegung sehen sie die Situation der Farbigen in den USA keineswegs als geklärt an. Unwissenheit und offen rassistische Behandlung durch staatliche Organe sind Zustände, die Public Enemy in ihren Statements anprangern...] Das Ziel von Public Enemy ist es, ihre Zuhörer dazu zu bringen, die Probleme zu erkennen. Und sie tun das mit ihren Raps ... Lauter als Bomben!' (Schramm 1988c) ${ }^{11}$
\end{abstract}

[As followers of Islam and advocates of the Black Panther movement, they don't regard the situation of colored people in the USA as settled. In their statements, Public Enemy decry the State's ignorance and patent racism ... It is Public Enemy's goal to get their listeners to understand these problems. And they do that with their raps ... Louder than bombs!]

As legitimate as it was to foreground ideology when talking about such a politically active group as Public Enemy, this kind of representation seems politically overcharged at the expense of adequate commentary on their musical achievements. Schramm concluded his review of It Takes a Nation of Millions to Hold Us Back with only a few remarks on their practice of rapping and deejaying, too few given that his teenage audience was more interested in the music than in ideology:

\begin{abstract}
Musikalisch sind Chuck D, Flavor Flav und ihr DJ Terminator X immer noch so ziemlich das härteste, was im Hip Hop Bereich geboten wird. Teilweise sind die Arrangements ganz minimal auf die donnernde Beatbox und die schwere Stimme von Chuck D gegründet. Flavor Flav lockert das ganze mit seinem fast jungehaft [sic] klingenden Gesangsorgan auf. Und ganz selten lässt sich Terminator X zu swingenden Einlagen hinreißen. Die allgefälligen James-Brown Scratche und andere poppigen Einlagen sind Tabu. (Schramm 1988c)

[Musically speaking, Chuck D, Flavor Flav, and their DJ, Terminator X, still offer the toughest that hip-hop currently has to offer. Their arrangements are partly, and quite minimally, based on Chuck D's thundering beat box and his heavy voice. Flavor Flav loosens up everything with his almost boyish sounding voice. And very rarely, Terminator $\mathrm{X}$ allows himself to perform some swinging interludes. The James-Brown scratches and other trendy gimmicks that you hear elsewhere are taboo.]
\end{abstract}

Although Lutz Schramm was not quite correct with his last statement - most pieces on the album indeed feature James Brown samples - this non-political part of the review was what the teenagers were looking for when they tuned into his show. In these smaller interludes, they could appreciate both the music and the moderation, since the ideological context was missing. In comparison with the cultural functionaries, who were at a loss with the music, the hip-hop heads emerged as the winners. By appropriating 'Vibrationen,' they turned a program that was designed to control them and their culture into something that was useful for their everyday practice of hip-hop. And ironically Schramm, the State's representative, thereby did more to foster the hiphop scene's creativity, than he did to guide it in 'appropriate' ways. His continuous

11 'Louder than a Bomb' was the next track Schramm played. 
eagerness to feature rap made in the GDR, for example, from SBJ in Arnstadt, the Electric Beat Crew in Berlin, or TJ Big Blaster Electric Boogie in Dresden, and to otherwise report on local hip-hop events functioned as great incentives for hip-hop heads in East Germany to remain active in the scene (Schramm n.d.; Schramm 1989). He nourished audiences' love for African American culture, and the ideas, information, and sounds he gave to the teenage audience proved to be vital for the hip-hop scene. On the other hand, packaging American rap as second culture seemed to be primarily about keeping politicians, functionaries, and other socialist officials calm about hip-hop culture.

\section{Performing blackness in graffiti: Simo from Dresden}

East German graffiti 'writers' not only expressed themselves visually; they also imagined themselves to be taking part in the transatlantic culture of hip-hop. They thus committed a temporary Republikflucht, a short break-out from a socialism they thought constrained them like a ghetto. But if they had to live in a ghetto, one could say that they preferred the Bronx to the GDR (DJ Opossum 2005). Consequently, these writers fashioned themselves as black teenagers roaming the Bronx. Their AfroAmericanophilia not only helped them to transcend the otherwise tightly sealed border to the west, it also led them, subconsciously, to take on a black identity. That is to say, they appropriated a black writer's identity, albeit without acknowledging the economic hardships, racial discrimination and gang violence that African American and Puerto Rican teenagers had to face on a daily basis in the Bronx in the 1980s. In this section I focus on the writer Simo from Dresden and show how he fashioned himself as a black graffiti artist from the Bronx in New York City. He is representative of many writers and b-boys in the GDR. ${ }^{12}$

Kai Simon from Dresden came to graffiti by way of breakdance (Simon 2008). Like others in his generation, he came into contact with hip-hop as a teenager (at age 14) after watching Beat Street in the summer of 1985 . He soon concentrated on painting graffiti. Taking his cue from Ramo, the graffiti-writer in Beat Street whose original name was Ramon, he dropped the final -n of his name and became Simo. Initially, he

\footnotetext{
${ }^{12}$ The documentary movie Here We Come, directed by Nico Raschick (2006), and its bonus material (on DVD), illustrate in great detail the visual practices of graffiti in the GDR, showing that the hip-hop heads used black motives in their graffiti and fashion (see the examples of Grandmaster Fight Machine, Beat Smith and Syntonic Force). See also Schmieding (2008b).
} 
mimetically copied what he saw in Beat Street, trying to be as precise as possible. Only later, starting in 1988, when he participated in local contests and workshops organized by the deejay and rapper TJ Big Blaster Electric Boogie, and began to build a network within the hip-hop scene, did he begin to create his own graffiti. It was then that he realized: 'That's me now-I'm a real artist' (Simon 2008). The exchange with other graffiti artists and the respect he gained in the process gave him the confidence to try out different styles and become an accomplished writer.

None of Simo's original graffiti 'pieces' in Dresden's public spaces has survived the last 25 years. Neither are there any photographs that could serve as documentation of his ephemeral art. Consequently, the only visual source testifying to his practice as a writer is his sketchbook, the so-called 'black book.' In it he drew studies and preliminary versions of the graffiti he intended to create. The book allows us to see how he conceptualized his art, the people he regarded as his greatest influences, and how he came of age as a graffiti writer in Dresden between 1986 and 1989.

On his black book covers (see figure 1), Simo visually represents his story of becoming a writer in the GDR. On the front, he copies the famous tag 'Wild Style' from the film of the same name and adds the well-known quotation 'It's about time we start gettin' some publicity for this rap shit' (Simon 1986b). He thereby offers a motto for his work - attracting the public's attention to hip-hop-but he also demonstrates that, at this early stage of his career, he is limited to copying his idols. In contrast, the back cover reveals a mature writer full of self-esteem and a clear sense of belonging: 'Power from the East Side' (Simon 1990a). With this tag, Simo locates himself in East Germany.

The graffiti in the black book bespeak his iconographic negotiation with the USA. They depict how he conceives of himself as a 'subway writer,' paying respect to hip-hop's pioneers in New York City, the cradle and capital of hip-hop (Simon 1986a; Simon 1987b). He lists famous rappers and deejays - Cool DJ Herc, Grandmaster Mel, and Afrika Bambaataa, all of whom starred in Beat Street (see figure 2) - and refers to all the hip-hop locations in town, also representing New York City's skyline, the Statue of Liberty and 'NY.' ${ }^{, 3}$ He thus makes New York his own, inscribing its hip-hop culture

\footnotetext{
${ }^{13}$ While listing the boroughs of New York, he makes the mistake of omitting Staten Island and includes Harlem instead, thus increasing the black space of the city that he references throughout his narrative (see figure 2).
} 
into his persona as a writer. What is more, he pictures himself as a black writer spraypainting with a personalized spray can, channeling his frustration into art in the Bronx (see figures 3 and 4; Simon 1987a; Simon 1988).

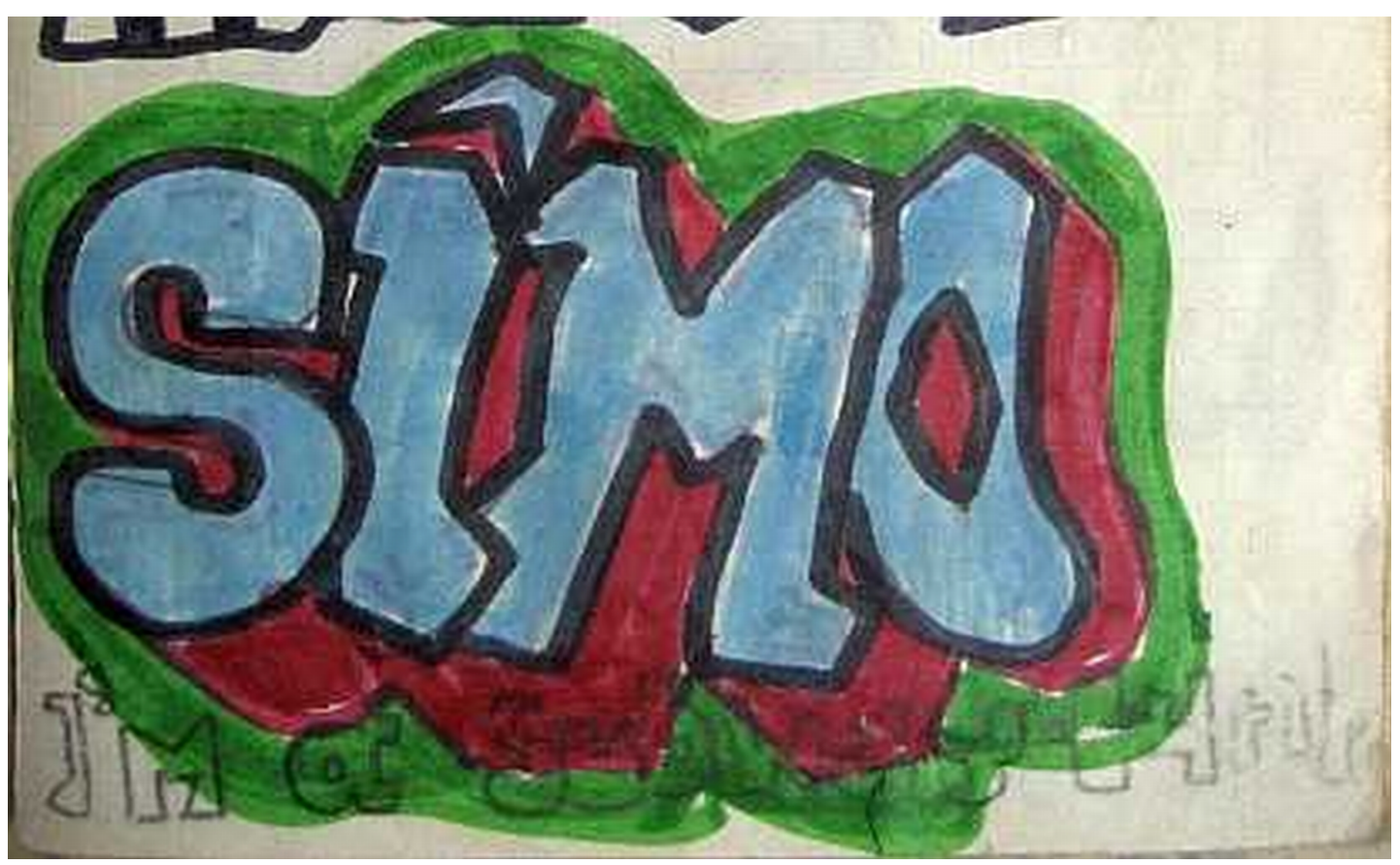

Figure 1: Simo. I'm a Subway Writer (C) Private collection Simo.

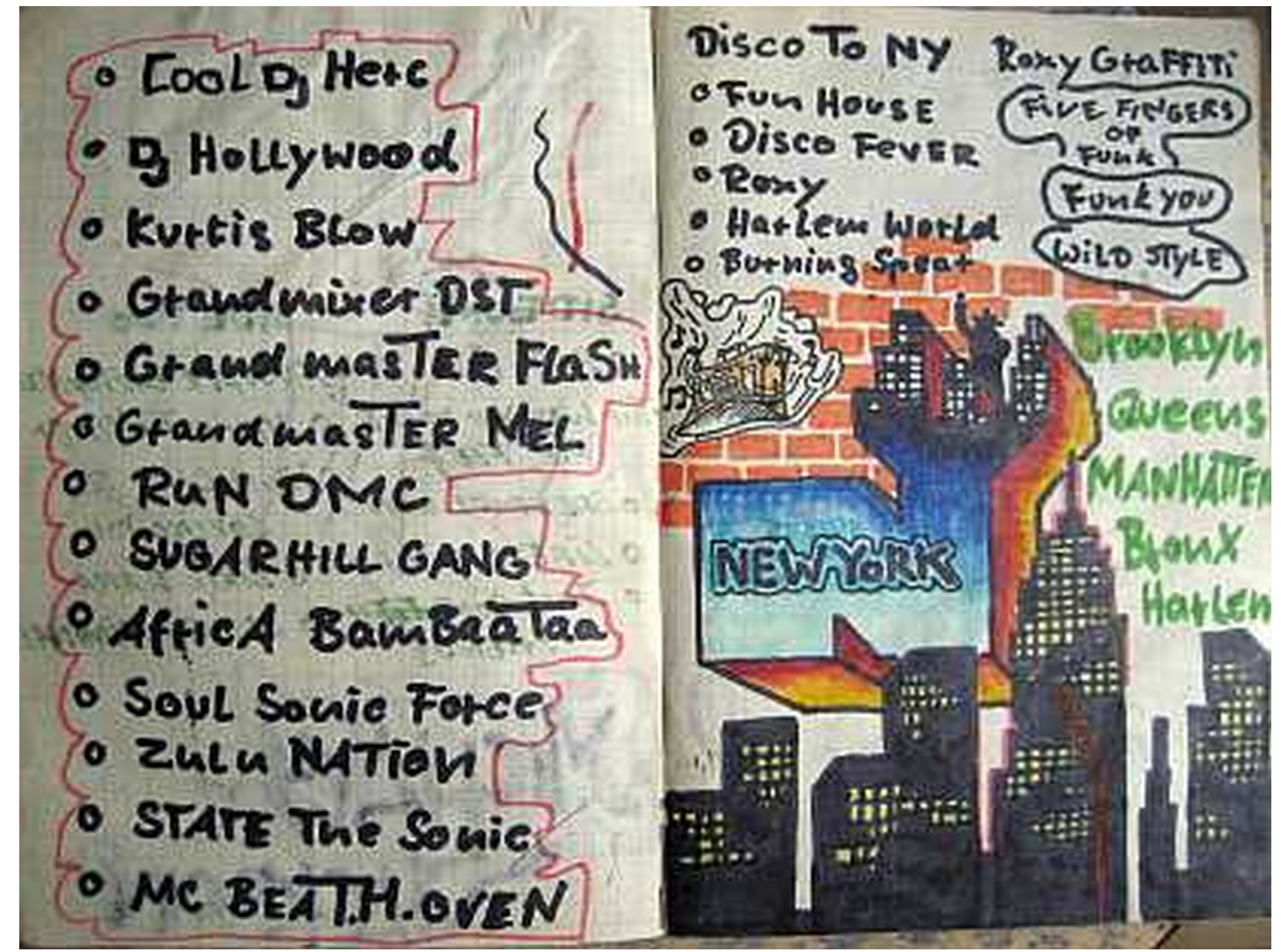

Figure 2: New York (C) private collection Simo. 


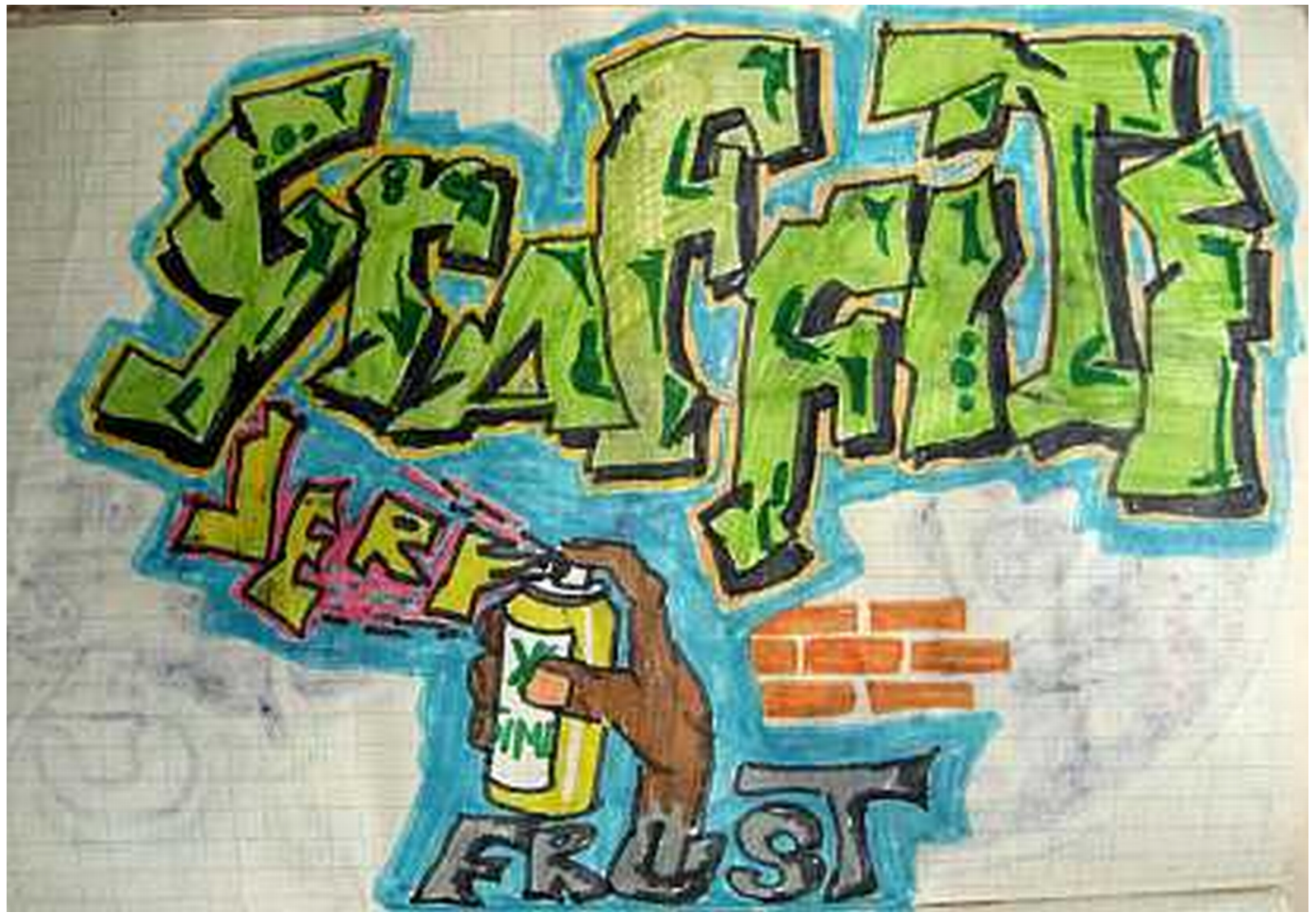

Figure 3: Graffiti Frust (C) private collection Simo.

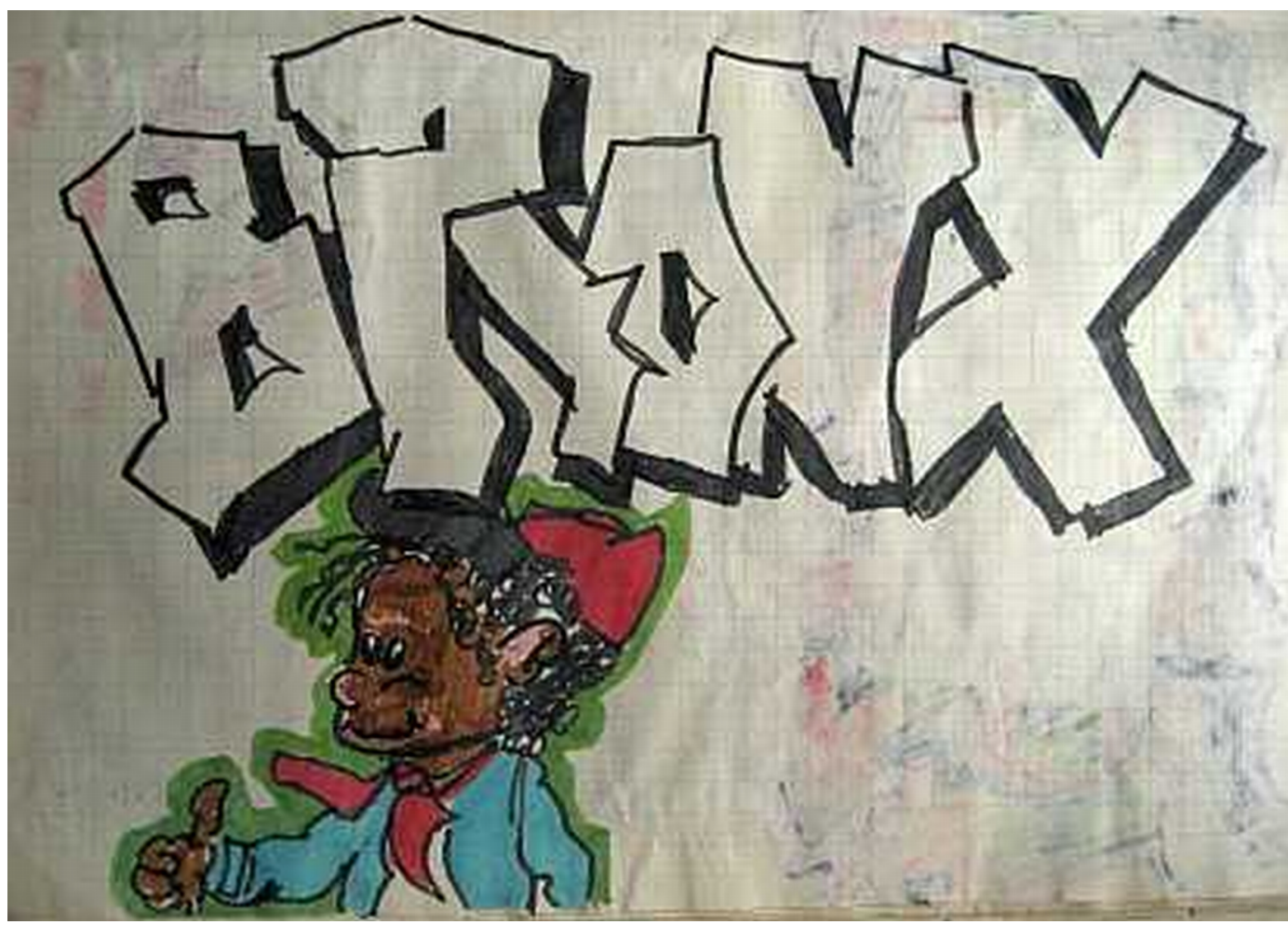

Figure 4: Bronx (C) private collection Simo.

Simo's mind was in an imaginary Bronx and his body in the local hip-hop scene in Dresden, a pattern he shared with hip-hop heads all over the GDR. He received his 
'Power from the East Side' by being part of an Afro-Americanophile audience participating in the transnational culture of hip-hop; an audience capable of transcending the Iron Curtain by practicing breakdance, graffiti, deejaying and rap in East Germany. Due to Simo's reputation, local hip-hop artists commissioned him to create graffiti for their own use. B-Boys asked him to design so-called 'backpieces' for their jackets and hoodies, to look 'fly' in the club and on the streets (Simon 2008). Rappers and deejays wanted his graffiti for the covers of their homemade musical productions and stage designs, or in order to advertise themselves. The following exchange between the music group A.B.R. and Simo's crew Drizzly Force exemplifies how such a collaboration worked:

Hallo Drizzly Force! Hier meldet sich das A.B.R.- Musikprojekt. Danke das (sic) ihr bereit seid das Graffiti zu "Zaubern” ... Übrigens, in Radebeul werden wir auch mit einer kleinen bis winzigen Graffiti vertreten sein ... Was die Graffiti betrifft wollen wir euch "freien Lauf" lassen. Ich würde sagen ihr macht einige Entwürfe und wenn wir uns mal treffen suchen wir uns gemeinsam die beste aus. OK? Eure [sic] Graffiti wird in Radebeul Rückendeckung gegeben, wir haben vor sie auf alle unsere Auftritte mitzunehmen. Du warst erstaunt das [sic] wir dir geschrieben haben. "Radebeul Veteranen" sind die echten!! (A. B. R.-Musikprojekt 1989)

[Hello Drizzly Force! This is the A.B.R. music project. Thanks for being willing to "whip up" your graffiti for us. We'll also be in Radebeul [for the rap contest], and we should meet there sometime ... Concerning the graffiti, please feel free to be "as creative as you want." I suggest you come up with some sketches, and when we meet we decide together which is the best. OK? We'll vote for your graffiti during the contest in Radebeul, and we want to display them on all of our gigs ... "Radebeul Veterans" are the real stuff!!]

This passage also shows how important self-organized hip-hop events like the one in Radebeul were. They were beyond the control of the cultural authorities and were important sites for exchanging materials, ideas, and practices among the hip-hop audience in the GDR.

The rap workshop in Radebeul in January 1989, organized as part of the Universal Hip Hop Family by the rapper TJ Big Blaster Electric Boogie from Dresden, was especially important for building the hip-hop scene in the GDR. It was also an important site for steering Afro-Americanophilia. TJ Big Blaster Electric Boogie carefully orchestrated young hip-hoppers imaginary and symbolic interaction with blackness by stressing in his rules and regulations that he wanted the participants to write original lyrics, and not just copy their African American idols (Figas 1989). In a letter of advice to his fellow rapper SBJ, he wrote:

allgemein, was Du zu Deinen plänen mit texten schreibst, ich rate Dir dringend davon ab in klischees zu verfallen und eine art einfachen weg zu gehen, indem man textzeilen übernimmt, 
nichts ist schlimmer als klauen. mach lieber grammatische fehler, habe lieber einen mittelmäßigen ausdruck, aber eigene texte. wenn Du englisch lernen willst, übersetze texte (lyrics) - entweder vorhandene die manchmal auf platten abgedruckt sind, oder versuch das zeug rauszuhören [sic]. (TJ Big Blaster Electric Boogie 1989)

[Concerning your plans with writing texts, I strongly advise against using clichés and thus taking the easy way out. Nothing is worse than stealing other people's text lines. It is better to make grammatical mistakes, better to have an only limited expression, as long as you have texts that you wrote yourself. If you want to learn English, translate lyrics - sometimes they're printed on the album covers, or try to transcribe them (sic).]

TJ Big Blaster Electric Boogie's insistence on originality reads like a plea for 'authenticity,' which, as Gabriele Klein and Malte Friedrich have argued, is the most important aesthetic value in hip-hop culture. Here, authenticity is to be achieved by appropriating hip-hop in the space between its 'original' from the Bronx and its 'original' on the performer's home turf, that is his or her local political, social, and cultural environment (Klein \& Friedrich 2003: 8-11). By composing lyrics, music, and graffiti which were largely inspired by hip-hop culture seen in Beat Street, hip-hop heads like SBJ, TJ Big Blaster Electric Boogie, and Simo were quite aware that they did not in fact live in the Bronx. However, they wanted to be as authentic as their idols, and in doing so they expressed a desire to escape the GDR in an imaginary manner.

If Simo earned respect within the hip-hop scene, he also met incomprehension by the police. Years after the fall of the Wall, in a questionnaire for a hip-hop magazine, he recounted an incident in Dresden, close to the youth club 'Scheune' [The Barn], which hosted the most famous hip-hop parties in town:

Eine dreiköpfige Gruppe von Möchtegern-“Sprühern” hat durch wundersame Weise ein paar Sprühdosen aus der CSSR bekommen. Endlich, die Nacht ist dunkel, die Straßen sind leer und wir 3 in froher Erwartung den nächsten Tag als richtige Sprüher oder noch besser WRITER zu erleben. Alles ist durchgeplant, leider reichen die Dosen nur für ein Bild, egal jeder darf und ganz alleine sprühen. Wir haben extra Kreide besorgt um nicht etwa wertvolle Sprühfarbe bei den Firstlines zu vergeuden. Wir sind an der Wand, nachts und mit Sprühdosen, was für ein Gefühl ... Aber was kann uns schon aufhalten? Schließlich haben wir alle mehr als 10 Mal Beat Street gesehen und da kletterte Lee auf die Schultern eines anderen. Auf Schultern stehen und mit einem Gefühl von Freiheit werden die ersten Striche mit Kreide gezogen. Als wie aus dem Nichts ein TRABBI auftaucht und in geringer Entfernung stehen bleibt ... Auf der Wache die übrigens gleich um die Ecke war wurden wir begafft wie Mohren im Zirkus um 1912. Alle Bullen ließen ihre Arbeit stehen und liegen um uns in Augenschein zu nehmen. Uns ging vielleicht der Arsch. Nachher mußten wir nur aufschreiben was und warum wir malen wollten. Wir durften sogar die Dosen behalten. Die haben wir dann im Adrenalinrausch alle vertaggt. (Simon 1990b)

[A group of three wannabe "sprayers" had miraculously gotten their hands on some spray cans from Czechoslovakia. Finally, the night is dark, the streets are empty, and we three are in happy anticipation of waking up the next morning as real WRITERS. Everything is planned out. Unfortunately, the cans only allow for one piece, but it doesn't matter, everybody can spray on his own. We brought chalk so as not to waste our precious paint on the firstlines. We're on the wall, at night, with spray cans, what a feeling ... What can possibly stop us? We have all seen Beat Street 
over and over, and have watched Lee standing on the shoulders of another writer in order to reach up high. So standing on shoulders, with a feeling of freedom, we're drawing the first lines with chalk. Then, out of nothing, a [police] TRABI [car] appears and comes to a halt a certain distance away ... Back at the station, which was just around the corner, by the way, they gazed at us as if we were Moors at a circus circa 1912. Every police officer stopped working just to stare at us. We were scared as hell. Eventually, though, we only had to state what and why we had wanted to paint. They even let us keep the cans. Full of adrenaline, we went tagging all over the city that night.]

Whilst this episode reveals how rarely young East German writers had the opportunity to use real spray cans, and how they went to great lengths to obtain them from a neighboring socialist country, it also discloses how incapable of deciphering hip-hop the police authorities in East Germany sometimes were. The police and the members of the Ministry for State Security (Stasi, or secret police) often used harsh measures against what they called 'defiling public property. ${ }^{14}$ In this case, however, Simo and his friends were lucky that the local officers were unable to comprehend the graffiti and dealt with them leniently.

\section{Conclusion}

In this article, I have analyzed an instance of East German Afro-Americanophilia by looking at the cultural transfer of hip-hop in the mid-to-late 1980s. I focused on three individuals who participated in this process at different levels. Cultural critic Erhart Ertel interpreted hip-hop as second culture and recommended it to be appropriated by youngsters in East Germany, thus paving the way for its incorporation into the socialist cultural landscape. Radio host Lutz Schramm played a more ambiguous role, on the one hand satisfying the authorities' demands to use the mass media for socialist education, and on the other hand feeding his teenage hip-hop audience the information and music necessary to create a hip-hop scene of their own. Graffiti writer Simo imagined himself to be living in the mecca of hip-hop, the Bronx, and he did so by fashioning himself as black in his graffiti.

In the last years of the GDR hip-hop-based Afro-Americanophilia maintained some characteristic patterns of engaging with blackness in East Germany. State-sponsored Afro-Americanophilia lauded hip-hop as second culture on the basis of its fight against capitalism and its authentic expression of a tough black life in the metropolis. On the other hand, hip-hop heads allied themselves imaginatively with their black idols, joining them in a struggle to break out of a ghetto communing between the GDR and the USA.

\footnotetext{
${ }^{14}$ For a case of the Ministry of State Security dealing with hip-hop graffiti, see Schmieding (2011).
} 
Similar ways of appropriating African American culture can be found in the immediate postwar era, and East Germany during the 1960s. Whether they dealt with jazz, rock ' $n$ ' roll, blues, or hip-hop — neither state nor teenagers changed distinctively in their AfroAmericanophilia.

\section{Reference List}

A. B. R.-Musikprojekt 1989, ‘Hallo Drizzly Force!’ Private collection Simo.

DJ Gambler 2008, Interview with the author, 5 April.

DJ Opossum 2005, Interview with the author, 15 November.

Ege, M. 2007, Schwarz werden: 'Afroamerikanophilie' in den 1960er und 1970er Jahren [Becoming Black: 'Afro-Americanophilia' in the 1960s and 1970s]. Transcript, Bielefeld. doi: http://dx.doi.org/10.14361/9783839405970

Ertel, E. 1985, 'Breakdance: Anmerkungen zu einer "zweiten Kultur”' [Breakdance: Notes on a 'Second Culture'], Informationen der Generaldirektion beim Komitee für Unterhaltungskunst [Information from the General Sub-Committee for the Entertainment Arts], no. 4 (October): 1-12.

Figas, P. 1989, 'DDR-offener Rap-Workshop im Jugendklub Nickern' [GDR Open Rap Workshop in the Nickern Youth Club]. Private collection Simo.

Fischer, D. 1983, New York: Glanz und Elend einer großen Stadt [New York: The Brilliance and Misery of a Big City]. Brockhaus, Leipzig.

Holdt, J. 1980, Amerikanische Bilder: eine Reise durch das schwarze Amerika [American Pictures: A Trip through Black America]. Verlag Volk und Welt, Berlin.

1984, Amerikanische Bilder: eine Reise durch das schwarze Amerika [American Pictures: A Trip through Black America] $3^{\text {rd }}$ edition. Verlag Volk und Welt, Berlin.

Hurley, A. W. 2009, The Return of Jazz: Joachim-Ernst Berendt and West German Cultural Change. Berghahn Books, New York \& Oxford.

Hyde, L. 1998, Trickster Makes This World: Mischief, Myth, and Art. Farrar, Straus and Giroux, New York.

Klein, G. \& Friedrich, M. 2003, Is this real? die Geschichte des HipHop [Is this Real? The History of Hip-hop]. Suhrkamp, Frankfurt am Main.

Kuczynski, J. 1982, 'Die zweite Kultur' [Second Culture], in Geschichte des Alltags des deutschen Volkes [A History of the German People's Everyday]. Akademie-Verlag, Berlin: 228-259.

Kusmierz, Z.A. 2002, 'Areas of Uncertainty: Observations on the German Reception of Spike Lee and HipHop Culture,' in Amerikanische Populärkultur in Deutschland [American Popular Culture in Germany], (eds) H. Paul \& K. Kanzler. Leipziger Universitätsverlag, Leipzig: 167-180.

Larkey, E. 2007, Rotes Rockradio: populäre Musik und die Kommerzialisierung des DDR-Rundfunks [Red Rock Radio: Popular Music and the Commercialisation of GDR Broadcasting]. Lit Verlag, Berlin.

Lenin, V. I. 1980, Kritische Bemerkungen zur nationalen Frage [Critical Remarks on the National Question]. Dietz, Berlin.

Poiger, U. G. 2002, Jazz, Rock, and Rebels: Cold War Politics and American Culture in a Divided Germany. University of California Press, Berkeley.

Raschick, N. (dir.) 2006, Here We Come, documentary. Filmakademie Baden-Württemberg, Ludwigsburg.

Rauhut, M. 2002, Rock in der DDR: 1964 bis 1989 [Rock in the GDR: 1964 until 1989]. Bundeszentrale für Politische Bildung, Bonn. 2011, 'The Voice of the Other America. African-American Music and Political Protest in the German Democratic Republic,' in Between the Avantgarde and the Everyday: Subversive Politics in Europe from 1957 to the Present, (eds) T. Brown \& L. Anton. Berghahn Books, New York: 92108.

Ribbat, C. 2000, 'How HipHop Hit Heidelberg. German Rappers, Rhymes, and Rhythms,' in 'Here, There, and Everywhere': The Foreign Politics of American Popular Culture, (eds) R. Wagnleitner \& E. Tyler May. University Press of New England, Hanover \& London: 207-216.

Salewski, F. 2012a, 'ein kleiner Beitrag!!' [A Small Contribution!!] Facebook: DT64_das Jugendradio $\operatorname{der} D D R$ [Facebook DT64 - the Youth Radio of the GDR], 29 August. 2012b, E-Mail to the author via Facebook, 29 August. 
Schmieding, L. 2008a, 'Of Windmills, Headspins, and Powermoves: Hiphop in the GDR 1983-1990,' in Ambivalent Americanizations. Popular and Consumer Culture in Central and Eastern Europe, (eds) S. M. Herrmann et al. Universitätsverlag Winter, Heidelberg: 65-85. 2008b, 'Das selbstgefertigte Ghetto-Outfit: HipHop-Mode in der DDR 1983-1990,' [The Homemade Ghetto-outfit: Hip-hop Fashion in the GDR, 1983-1990], Horch und Guck [Listen and Look], vol. 61, no. 3: 38-42. . 2011, 'Boom Boxes and Backward Caps: Hip-Hop Culture in the GDR,' in East German Material Culture and the Power of Memory, (eds) U. Balbier, C. Cuevas-Wolf \& J. Segal. Bulletin of the German Historical Institute, Washington, DC: 67-86.

2012, 'Taking Beat Street to the Streets in Socialist East Germany,' in Participating Audiences and Imagined Communities: The Cultural Work of Contemporary American(ized) Narratives, (eds) S. M. Herrmann et al. Leipziger Universitätsverlag, Leipzig: 43-61.

Schramm, L. 1988a, Hörerpostsendung: Rap/Musik-Mix [Listeners' Mail: Rap/Music Mix]. Private archive L. Schramm. 1988b, Vibrationen [Vibrations] episode 13 January 1988. Jugendradio DT 64 [Youth Radio DT64]. Private archive L. Schramm. 1988c, Vibrationen [Vibrations] episode 21 September1988. Jugendradio DT 64 [Youth Radio DT64]. Private archive L. Schramm. . 1989, Vibrationen [Vibrations] episode 26 January 1989. Jugendradio DT 64 [Youth Radio DT64]. Private archive L. Schramm. n. d., Letter to SBJ. Private collection SBJ.

Simon, K. 1986a, Simo. I'm a Subway-Writer. Private collection Simo. 1986b, Wild Style. Private collection Simo. 1987a, Graffiti Frust [Graffiti Frustration]. Private collection Simo. 1987b, New York. Private collection Simo. 1988, Bronx. Private collection Simo. 1990a, Power from the Eastside. Private collection Simo. 1990b, 'Umfrage eines Fanzines zu Graffiti' [Fanzine Questionnaire on Graffiti]. Private collection Simo. 2008, Interview with the author, 5 April.

TJ Big Blaster Electric Boogie 1989, 'Ich fürchte, das Hin und Her läßt sich nicht sparen' [I'm Afraid You Can't Avoid the To and Fro]. Private collection SBJ.

TJ Big Blaster Electric Boogie, Andy K \& Tommy 2008, Interview with the author, 29 February. 